\title{
Antiestrogen-resistant human breast cancer cells require activated Protein Kinase B/Akt for growth
}

\author{
T Frogne, J S Jepsen, S S Larsen, C K Fog, B L Brockdorff and A E Lykkesfeldt
}

Department of Tumor Endocrinology, Institute of Cancer Biology, Danish Cancer Society, Strandboulevarden 49, DK-2100 Copenhagen, Denmark

(Requests for offprints should be addressed to A E Lykkesfeldt; Email: al@cancer.dk)

\begin{abstract}
Development of acquired resistance to antiestrogens is a major clinical problem in endocrine treatment of breast cancer patients. The IGF system plays a profound role in many cancer types, including breast cancer. Thus, overexpression and/or constitutive activation of the IGF-I receptor (IGF-IR) or different components of the IGF-IR signaling pathway have been reported to render breast cancer cells less estrogen dependent and capable of sustaining cell proliferation in the presence of antiestrogens. In this study, growth of the antiestrogen-sensitive human breast cancer cell line MCF-7 was inhibited by treatment with IGF-IR-neutralizing antibodies. In contrast, IGFIR-neutralizing antibodies had no effect on growth of two different antiestrogen-resistant MCF-7 sublines. A panel of antiestrogen-resistant cell lines was investigated for expression of IGF-IR and either undetectable or severely reduced IGF-IR levels were observed. No increase in insulin receptor substrate 1 (IRS-1) or total PKB/Akt (Akt) was detected in the resistant cell lines. However, a significant increase in phosphorylated Akt (pAkt) was found in four of six antiestrogen-resistant cell lines. Overexpression of pAkt was associated with increased Akt kinase activity in both a tamoxifenand an ICl 182,780-resistant cell line. Inhibition of Akt phosphorylation by the phosphatidylinositol 3-kinase (PI3-K) inhibitor wortmannin or the Akt inhibitor SH-6 (structurally modified phosphatidyl inositol ether liquid analog PIA 6) resulted in a more pronounced growth inhibitory effect on the antiestrogen-resistant cells compared with the parental cells, suggesting that signaling via Akt is required for antiestrogen-resistant cell growth in at least a subset of our antiestrogen-resistant cell lines. PTEN expression and activity was not decreased in cell lines overexpressing pAkt. Our data demonstrate that Akt is a target for treatment of antiestrogen-resistant breast cancer cell lines and we suggest that antiestrogen-resistant breast cancer patients may benefit from treatment targeted to inhibit Akt signaling.

Endocrine-Related Cancer (2005) 12 599-614
\end{abstract}

\section{Introduction}

The antiestrogen tamoxifen has been first-line endocrine therapy for estrogen receptor (ER) positive breast cancer patients for more than 25 years, and several other antiestrogens and selective ER modulators (SERMs) have also been approved for treatment, including the pure steroidal antiestrogen ICI 182,780 (Faslodex, Fulvestrant) (Howell \& Howell 2003). Many patients benefit from treatment with endocrine agents, but patients with advanced disease and initially responsive tumors will eventually develop resistance (Osborne 1998). Development of acquired resistance to endocrine therapy does not exclude response to other types of treatments including other endocrine agents (Come et al. 2003) and knowledge of the molecular mechanisms responsible for resistance is extremely important to find efficient treatment for resistant tumors.

A multitude of alterations in the initially hormoneresponsive breast cancer cells may lead to acquired resistance. The most obvious alteration is loss of 
expression of the ER, which is a prerequisite for response to estrogens. However, many tumors acquire resistance without loss of ER expression (Encarnacion et al. 1993, Johnston et al. 1995). Endocrine resistance may also be caused by altered signal transduction arising from increased growth factor or growth factor receptor expression, from cross-talk between signal transduction pathways, changes in ER $\alpha$ co-regulator proteins, or from deregulation of important factors in the signaling pathways (Ali \& Coombes 2002, Clarke et al. 2003, Johnston et al. 2003, Schiff et al. 2004).

In vitro cell cultures are useful models to test whether a change found to be correlated with resistance is causally involved in the resistant phenotype. Thus, increased expression levels of growth factors, receptors and signaling molecules may be annulled by treatment with neutralizing antibodies, small molecule kinase inhibitors, antisense RNA or small interfering RNA (siRNA). In a cell culture model system with the human breast cancer cell line MCF-7 grown in steroiddepleted fetal calf serum, cell lines with acquired resistance to tamoxifen or to ICI 182,780 have been established by continuous exposure to a growthinhibiting concentration of 4-OH-tamoxifen (100 nM) or $100 \mathrm{nM}$ ICI 182,780 (McClelland et al. 2001, Hutcheson et al. 2003). Both the ICI 182,780-resistant and the tamoxifen-resistant cell line displayed increased epidermal growth factor receptor (EGFR) expression and mitogen-activated protein kinase (MAPK) signaling, and growth of the resistant cell lines could be inhibited by treatment with an EGFR-specific tyrosine kinase inhibitor, ZD1839 (Iressa, Astra Zeneca, UK) (McClelland et al. 2001, Knowlden et al. 2003). These studies clearly demonstrate that aquired resistance to antiestrogen treatment may arise by a shift from estrogen-dependent growth to EGFR/MAPK-dependent growth.

In our laboratory, we have developed cell lines with acquired antiestrogen resistance to several welldescribed antiestrogens: tamoxifen, ICI 164,384, ICI 182,780 and the very potent pure steroidal antiestrogen RU 58,668 (Lykkesfeldt et al. 1994, 1995, Van de Velde et al. 1996, Madsen et al. 1997, Fog et al. 2005). Our design for establishing resistant cell lines has been to adapt MCF-7 cells to grow with a low amount of fetal calf serum (FCS; $1 \%$ ) containing estrogenic compounds corresponding to the level in the serum from postmenopausal women (Briand \& Lykkesfeldt 1984). These MCF-7 cells have been treated with a concentration of the antiestrogens, which gives complete growth arrest. However, after several weeks of treatment, resistant colonies slowly emerged (Lykkesfeldt et al. 1984), and we assume that genetic variants already present in the cell culture at the onset of treatment had gained a selection benefit (Lykkesfeldt et al. 1995). This assumption is supported by our observation that the resistant cell lines also continue to maintain resistance after long-time withdrawal from the selection pressure (Lykkesfeldt et al. 1994, 1995, Fog et al. 2005). In contrast to the cell lines developed in Nicholson's laboratory (McClelland et al. 2001, Hutcheson et al. 2003), our cell lines have very low EGFR expression, unaltered ErbB-2 levels and are unresponsive to treatment with Herceptin (Roche, Switzerland), which blocks signaling from ErbB-2 receptors (Larsen et al. 1999, de Cremoux et al. 2003). The cell lines continue to express ER $\alpha$ although at a reduced level (Lykkesfeldt et al. 1994, Larsen et al. 1997, Madsen et al. 1997), and no changes in the ER $\alpha$ co-regulators AIB1, TIF-1, SUG-1, RIP140 and SMRT have been found (Chan et al. 1999, de Cremoux et al. 2003). The ER $\beta$ level is extremely low in both parental MCF-7 cells and the antiestrogen-resistant cell lines (de Cremoux et al. 2003). Since the EGFR and ErbB2 receptors do not appear to be causally involved in antiestrogen resistance in this model system, we have investigated the IGF-I receptor (IGF-IR) signaling pathway. The IGF-IR is an estrogen-inducible protein (Stewart et al. 1990), and both the IGF-IR and the ligands IGF-I and -II are important for growth and survival of breast cancer cells (Arteaga \& Osborne 1989, Baserga et al. 1997, Jerome et al. 2003). Furthermore, increased signaling via IGF-IR, and increased level of insulin receptor substrate 1 (IRS-1), phosphatidylinositol 3-kinase (PI3-K) and Akt may also lead to antiestrogen resistance (Wiseman et al. 1993, Ahmad et al. 1999, Salerno et al. 1999, Campbell et al. 2001, Vivanco \& Sawyers 2002). Therefore, in this study we have examined whether factors in the IGF-IR signaling pathway are altered in the resistant cells. The study includes: growth analyses with neutralizing antibodies to IGF-IR; determination of expression and hormonal regulation of IGF-IR, IRS-1, Akt and pAkt; measurement of Akt kinase activity; and investigation of the effect of treatment with the PI3-K inhibitors wortmannin and LY294002 (Davies et al. 2000) and the Akt inhibitor SH-6 (Kozikowski et al. 2003, Castillo et al. 2004) on pAkt expression and cell growth. Finally, it was investigated whether the increased level of pAkt in antiestrogen-resistant cell lines was concomitant with a decreased level or activity of the PTEN tumor suppressor protein. PTEN dephosphorylates phosphatidylinositol 3,4,5-trisphosphate (PIP-3), which serves as a second messenger involved in activation of Akt ( $\mathrm{Li}$ et al. 1998). Figure 1 is a 


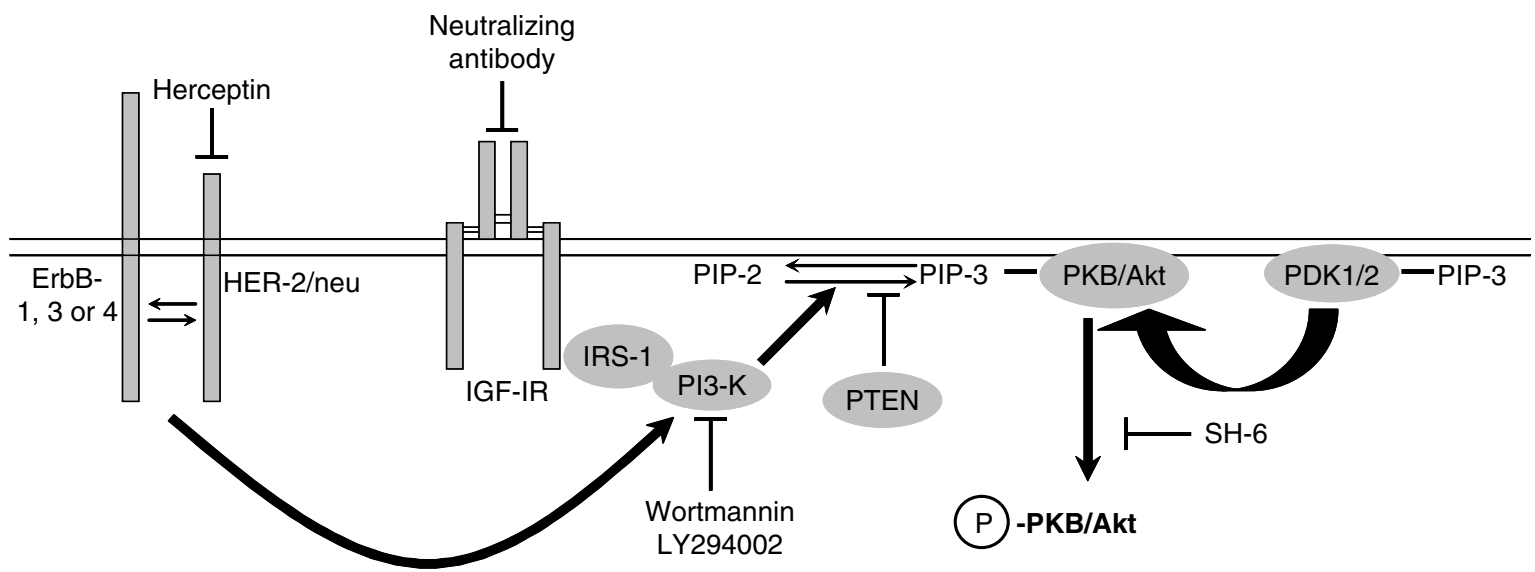

Figure 1 Activation of PKB/Akt (Akt). Activation of receptors in both the ErbB family and the IGF-IR result in signaling through PI3-K and Akt. IRS-1 is phosphorylated by activated IGF-IR and interacts with the p85 subunit of the PI3-K relieving the inhibitory action of p85 on the p110 catalytic subunit, which converts phosphatidylinositol 2-phosphate (PIP-2) to PIP-3. PIP-3 production induces membrane localization of Akt and phosphorylation of Akt by 3-phosphoinositide dependent protein kinase (PDK)1 and PDK2 (Vivanco \& Sawyers 2002). Signaling from ErbB-2 heterodimers is inhibited by the humanized rat monoclonal antibody Herceptin and signaling from the IGF-IR can be inhibited by the neutralizing antibody $\alpha$-IR3. The activity of PI3-K can be inhibited by wortmannin and LY 294002, whereas SH-6 is an inhibitor of Akt phosphorylation. The tumor suppressor gene PTEN encodes a phosphatase, which dephosphorylates PIP-3 to PIP-2.

simplified illustration of the signaling from the ErbB and the IGF-I receptors, including the compounds that have been analysed in this or previous studies from our laboratory.

\section{Materials and Methods}

\section{Cells and growth experiments}

The MCF-7 cell line was originally obtained from the Human Cell Culture Bank (Mason Research Institute, Rockville, MD, USA). The MCF-7 cells are routinely propagated in control growth medium consisting of phenol-red-free Dulbecco's modified Eagle's medium/ F12 (1:1) (Life Technologies) supplemented with 1\% FCS, Glutamax $2.5 \mathrm{mM}$ and $6 \mathrm{ng} / \mathrm{ml}$ insulin (NovoNordisk, Copenhagen, Denmark). The resistant cell lines: MCF-7/TAM $^{\mathrm{R}}-1$, MCF-7/TAM ${ }^{\mathrm{R}}-4$, MCF-7/ TAM $^{\mathrm{R}}-7, \quad \mathrm{MCF}-7 / 182^{\mathrm{R}}-1, \quad \mathrm{MCF}-7 / 182^{\mathrm{R}}-6, \quad \mathrm{MCF}-7 /$ $182^{\mathrm{R}}-7, \mathrm{MCF}-7 / 164^{\mathrm{R}}-5$ and $\mathrm{MCF}-7 / \mathrm{RU}^{\mathrm{R}} 8^{\mathrm{R}}-1$ were established as described previously (Lykkesfeldt et al. 1994, 1995, Madsen et al. 1997, Fog et al. 2005). Tamoxifen-resistant cell lines were maintained in control growth medium supplemented with $1 \mu \mathrm{M}$ tamoxifen-, ICI 182,780- and ICI 164,384-resistant cell lines in control growth medium supplemented with $100 \mathrm{nM}$ ICI 182,780 , and the MCF-7/RU58 ${ }^{\mathrm{R}}-1$ cells were grown with $1 \mathrm{nM}$ RU 58,668 (maintenance medium). Stock solutions of $10 \mathrm{mM}$ estradiol (Sigma), $1 \mathrm{mM}$ tamoxifen (Sigma), 0.1 mM ICI 182,780 (Zeneca
Pharmaceuticals, Macclesfield, UK), and $1 \mathrm{mMRU}$ 58,668 (Roussel Uclaf, Paris, France) were dissolved in $96 \%$ ethanol.

\section{Neutralization of IGF-IR with $\alpha / R-3$}

$\mathrm{MCF}-7 / \mathrm{TAM}^{\mathrm{R}}-1$ and $\mathrm{MCF}-7 / 182^{\mathrm{R}}-6$ cells were grown for 1 week without antiestrogen before the onset of the experiment. The MCF-7, MCF-7/TAM ${ }^{\mathrm{R}}-1$ and MCF-7/182 ${ }^{\mathrm{R}}-6$ cells $\left(1.25 \times 10^{4}\right.$ cells $\left./ \mathrm{cm}^{2}\right)$ were seeded in $2 \mathrm{~cm}^{2}$ multiwell dishes (Nunc, Roskilde, Denmark) in control growth medium. Two days after seeding, experimental medium containing vehicle $(0.1 \%$ ethanol, control), $100 \mathrm{nM}$ ICI 182,780 or $2 \mu \mathrm{M}$ tamoxifen alone or in combination with $1 \mu \mathrm{g} / \mathrm{ml}$ monoclonal antibody, $\alpha I R-3$, were added (IGF-IR monoclonal antibody without sodium azide, clone $\alpha$ IR-3, GR11L, Oncogene Research Products, Cambridge, MA, USA). Control antibody, purified mouse immunoglobulin (Ig) $\mathrm{G}_{1}$ (ICN Pharmaceuticals, Aurora, OH, USA), was used at $1 \mu \mathrm{g} / \mathrm{ml}$. Medium was changed every second or third day during the experiment. Four wells were used for each cell number determination (BürkerTürck chamber), which occurred at day 6 .

For the PI3-K and Akt inhibitor experiments, the MCF-7, MCF-7/TAM ${ }^{\mathrm{R}}-1, \mathrm{MCF}-7 / 182^{\mathrm{R}}-6$ and MCF$7 / \mathrm{RU} 58^{\mathrm{R}}-1$ cells were seeded in $2 \mathrm{~cm}^{2}$ multiwell dishes in maintenance medium. Two days after seeding, experimental medium containing either vehicle $(0.1 \%$ dimethyl sulfoxide (DMSO)), or increasing concentration of the PI3-K inhibitors LY294002 or wortmannin 
(Cell Signaling, Beverly, MA, USA) or the Akt inhibitor SH-6 (D-2, 3-Dideoxy-myo-inositol 1-[(R)2-methoxy-3-(octadecyloxy) propyl hydrogen phosphate] (Alexis, Switzerland) were added. Medium was renewed after 3 days, and cell number determination was performed at day 6 with a colorimetric assay (Lundholt et al. 2001). All inhibitors were tested at least three times with reproducible results.

\section{Western blot analysis}

MCF-7, MCF-7/TAM ${ }^{\mathrm{R}}-1$, MCF-7/TAM ${ }^{\mathrm{R}}-4$, MCF-7/ $\mathrm{TAM}^{\mathrm{R}}-7, \quad \mathrm{MCF}-7 / 182^{\mathrm{R}}-1, \quad \mathrm{MCF}-7 / 182^{\mathrm{R}}-6, \mathrm{MCF}-7 /$ $182^{\mathrm{R}}-7$, MCF-7/164 ${ }^{\mathrm{R}}-5$ and MCF-7/RU58 ${ }^{\mathrm{R}}-1$ were seeded in T25 flasks (Nunc) in control medium (MCF-7) or maintenance medium (containing the respective antiestrogen). Two days after seeding, experimental medium was added and renewed every second or third day. After 3-6 days, the cells were washed with PBS and harvested in radioimmunoprecipitation (RIPA) buffer or Pagano buffer containing phosphatase and protease inhibitors (Pagano et al. 1993); 10-30 $\mu \mathrm{g}$ total protein per sample (determined by BioRad protein assay kit, Munich, Germany) were separated on 10 or $15 \%$ SDS-PAGE gels under reducing conditions. The proteins were transferred to an Immobilon-P membrane (Millipore, Bedford, MA, USA) by semi-dry electroblotting. Immunostaining was performed with antibodies against: IGF-IR subunit $\alpha$ (N-20; Santa Cruz Biotechnology, Santa Cruz, CA, USA), IRS-1 (06-248; UBI, Lake Placid, NY, USA), pAkt and Akt (9271 and 9272 respectively, Cell Signaling), and PTEN (9556, Cell Signaling). Secondary goat-anti-rabbit and rabbit-anti-mouse horseradish peroxidase-conjugated antibodies (P0448 and P0260 respectively; DAKO, Glostrup, Denmark) were used. The blots were stripped and reprobed with a primary mouse monoclonal antibody against human keratin 7 (antibody kindly provided by Dr Jiri Bartek, Danish Cancer Society) or Akt as a control for differences in protein loading. The enhanced chemiluminescence (ECL ${ }^{\text {PLUS }}$ ) detection system (Amersham) was used for visualization of the proteins according to the manufacturer's instructions. Western blot analyses were repeated at least three times on independent cell lysates with reproducible results. Quantifications were performed with the Fujifilm LAS-1000 detection system (Fujifilm, Sweden) and ImageGauge software.

\section{Akt kinase activity}

The Akt kinase assay kit from Cell Signaling was used for determination of Akt activity in MCF-7 cells and antiestrogen-resistant cell lines. MCF-7 cells and antiestrogen-resistant cell lines were grown with their respective antiestrogen, $1 \mu \mathrm{M}$ tamoxifen or $100 \mathrm{nM} \mathrm{ICI}$ 182,780 until $60-70 \%$ confluence. Immunoprecipitation of $100 \mu \mathrm{g}$ protein from each sample was performed with immobilized Akt monoclonal antibody according to the manufacturer's description. Glycogen synthase kinase 3 (GSK-3) fusion protein was used as substrate in the kinase assay and the amount of phospho-GSK$3 \alpha / \beta$ was detected by Western blot analysis with phospho-GSK-3 $\alpha / \beta$-specific antibody supplied in the kit and quantified with the Fujifilm LAS-1000 detection system and ImageGauge software.

\section{PTEN phosphatase assay}

The assay was performed essentially as described in detail by Georgescu et al. (1999). Sixty to seventy per cent confluent cultures were harvested by trypsination, washed with ice-cool PBS and stored at $-80^{\circ} \mathrm{C}$ until use. The cells were lysed with Pagano buffer (without phosphatase inhibitors) (Pagano et al. 1993); $2 \mathrm{mg}$ protein from each sample was immunoprecipitated with rabbit antibodies to PTEN (9552, Cell Signaling) and precipitated with protein A agarose beads (Santa Cruz Laboratories). The phosphatase activity was measured with PIP-3 (P-3908, Echelon, Salt Lake City, UT, USA) as substrate and the released phosphate was measured in a colorimetric assay with Biomol Green reagent (Biomol, Plymouth Meeting, PA, USA), according to the manufacturer's instruction. Western blotting was performed in parallel to verify each immunoprecipitation used in the phosphatase assay. The primary antibody to PTEN was mouse monoclonal (9556, Cell Signaling) and the secondary antibody a cross-absorbed sheep anti-mouse antibody (NA931V, Amersham).

\section{Statistical analysis}

Factorial ANOVA and two-sample unequal variance $t$-test was used to evaluate whether the observed differences in growth and protein expression, respectively, were statistically significant. $P<0.05$ was used as the level of significance.

\section{Results}

\section{Effect of neutralizing antibodies to IGF-IR on growth of MCF-7 cells and antiestrogen-resistant cells}

The importance of signaling through the IGF-IR for growth of the antiestrogen-sensitive MCF-7 cell 

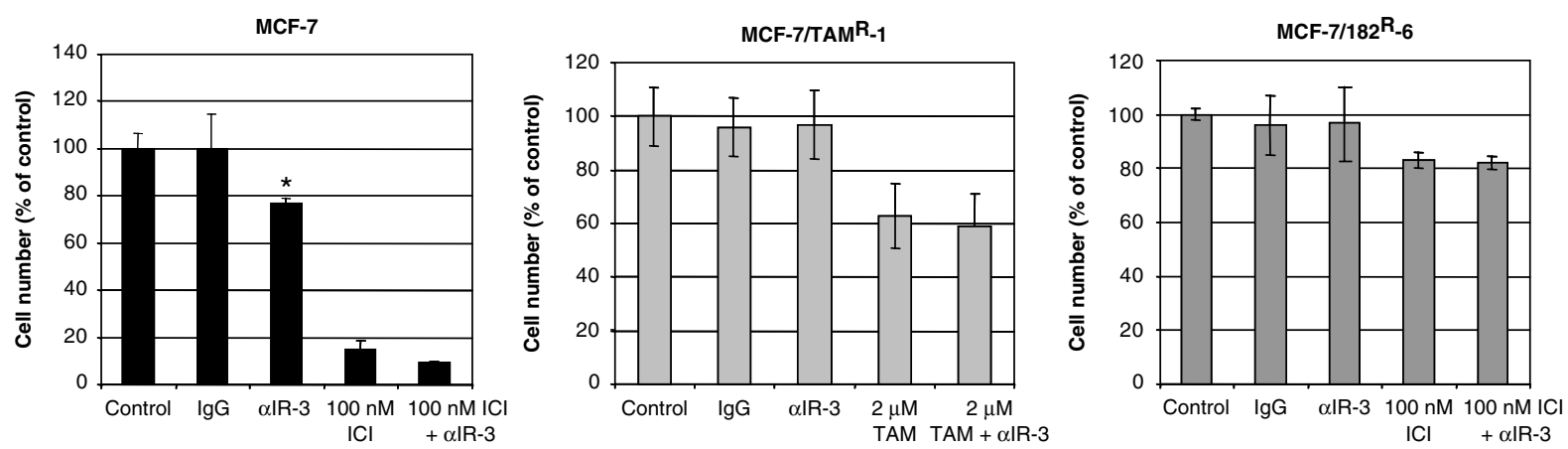

Figure 2 Growth effect after 6 days of treatment with ICI 182,780 (ICI), tamoxifen (TAM) and the anti-IGF-IR antibody $\alpha-I R 3$. MCF-7 cells and MCF-7/182 ${ }^{\mathrm{R}}-6$ cells were treated with the control mouse antibody $\left(\mathrm{IgG}_{1}, 1 \mu \mathrm{g} / \mathrm{ml}\right), 100 \mathrm{nM} I \mathrm{Cl} 182,780$, or anti-IGF-IR antibody $(\alpha-I R 3,1 \mu \mathrm{g} / \mathrm{ml})$ alone or in combination with $100 \mathrm{nM} \mathrm{ICl} \mathrm{182,780.} \mathrm{MCF}^{-7 / T A M}{ }^{\mathrm{R}}-1 \mathrm{cells}$ were treated with IgG ${ }_{1}$, $2 \mu \mathrm{M}$ tamoxifen, or $\alpha-\mathrm{IR} 3$ alone or in combination with $2 \mu \mathrm{M}$ tamoxifen. Mean values ( \pm S.D.) of cell numbers in quadruplicate wells (expressed as percentage of the corresponding control culture without antiestrogen) are shown. The results are from one representative experiment out of three independent experiments with reproducible results. *Statistically significant difference between $\alpha$-IR3-treated MCF-7 cells and both control MCF-7 and IgG-treated MCF-7 cells.

line and two antiestrogen-resistant cell lines, MCF$7 / \mathrm{TAM}^{\mathrm{R}}-1$ and $\mathrm{MCF}-7 / 182^{\mathrm{R}}-6$, was investigated by the use of the $\alpha$-IR3 antibody, which blocks IGF-I binding to the IGF-IR (Arteaga \& Osborne 1989).

Growth of MCF-7 cells was significantly inhibited by treatment with $\alpha$-IR3, whereas the control antibody had no effect on growth (Fig. 2). The mean level of growth inhibition with $\alpha$-IR3 was $23 \%(P=0.003)$. Two additional experiments, each with four controls and four treated cultures, also resulted in significant growth inhibition with $\alpha$-IR3 of 17 and $19 \%$. Treatment with the pure antiestrogen ICI 182,780 $(100 \mathrm{nM})$ significantly inhibits growth of MCF-7 cells down to $15 \%$ of control, and combined treatment with ICI 182,780 and $\alpha$-IR3 results in a further small inhibition of growth to $9 \%$ of control (Fig. 2). These data demonstrate that signaling via IGF-IR is important for growth of MCF-7 cells.

The antiestrogen-resistant cell lines MCF-7/ $\mathrm{TAM}^{\mathrm{R}}-1$ and $\mathrm{MCF}-7 / 182^{\mathrm{R}}-6$ can be propagated continuously in the presence of high concentrations of the respective antiestrogen: $1 \mu \mathrm{M}$ tamoxifen (or $2 \mu \mathrm{M}$ tamoxifen in this particular set of experiments) and $100 \mathrm{nM}$ ICI 182,780 . However, the growth rate of the cultures in maintenance medium is slightly lower than without antiestrogen as can be seen from the lower total number of cells in the cultures grown with antiestrogen compared with the control cultures, which in this experiment were grown without antiestrogen (Fig. 2). Treatment of these cell lines with $\alpha$-IR3 has no effect on growth, neither in the absence nor in the presence of antiestrogen (Fig. 2). These results suggest that acquired antiestrogen resistance in these cell lines does not emerge from activation of the IGF-IR through ligand binding.

\section{IGF-IR expression and regulation}

A panel of tamoxifen- and ICI 182,780-resistant cell lines was examined for IGF-IR expression, and the estrogen and antiestrogen regulation of IGF-IR was determined in the MCF-7 and the MCF-7/182 ${ }^{\mathrm{R}}-6$ cell line in order to elucidate whether alterations in IGF-IR expression or regulation may explain the lack of response to the neutralizing antibody $\alpha$-IR 3 in antiestrogen-resistant cells.

Polyclonal antibodies, which detect the $\alpha$-chain of the IGF-IR, were used to determine the expression of IGF-IR by Western blot analysis. A strong band of IGF-IR $\alpha$ protein was found in MCF-7 cells (Fig. 3A). No detectable amount of IGF-IR $\alpha$ was found in the three ICI 182,780-resistant cell lines and the MCF-7/ $\mathrm{TAM}^{\mathrm{R}}-4$ cell line, whereas low IGF-IR $\alpha$ amounts were detected in MCF-7/TAM ${ }^{\mathrm{R}}-1$ and MCF-7TAM ${ }^{\mathrm{R}}-7$ cells (Fig. 3A).

In MCF-7 cells, treatment with $1 \mathrm{nM}$ estradiol for 6 days exerts the expected increase in the expression of IGF-IR protein (Stewart et al. 1990), whereas tamoxifen $(1 \mu \mathrm{M})$ and ICI $182,780(100 \mathrm{nM})$ reduce the expression to very low or to undetectable levels respectively (Fig. 3B). The MCF-7/182 ${ }^{\mathrm{R}}-6$ cells do not express measurable amounts of IGF-IR when grown in control medium (15 days without ICI 182,780) and addition of estradiol or antiestrogens for 6 days does not give rise to detectable IGF-IR levels (Fig. 3B). These data show that the antiestrogen-resistant cell lines have either lost or have a severely reduced level of 
A

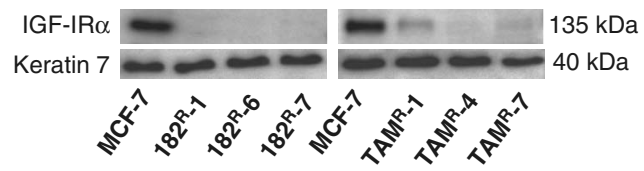

B

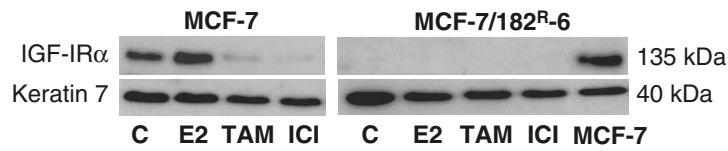

C

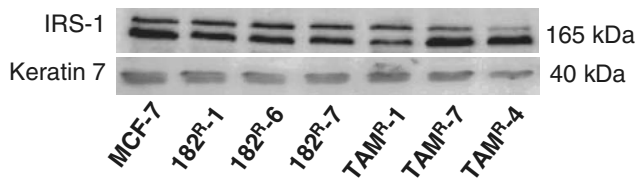

D

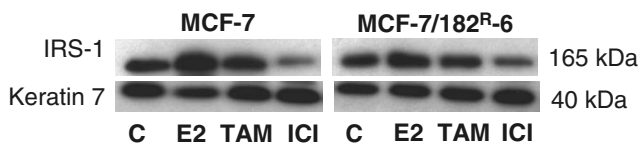

Figure 3 IGF-IR and IRS-1 protein expression and regulation in MCF-7 cells and in antiestrogen-resistant sublines. IGF-IR expression (A) and IRS-1 expression (C) in MCF-7 cells, three ICl 182,780-resistant cell lines (MCF-7/182 ${ }^{\mathrm{R}}-1$, MCF-7/182 ${ }^{\mathrm{R}}-6$ and $\left.M C F-7 / 182^{\mathrm{R}}-7\right)$ and three tamoxifen-resistant cell lines (MCF-7/TAM $^{\mathrm{R}}-1$, MCF-7/TAM ${ }^{\mathrm{R}}-4$ and MCF-7/TAM ${ }^{\mathrm{R}}-7$ ). Hormonal regulation of the IGF-IR (B) and IRS-1 protein (D) in MCF-7 and MCF-7/182 ${ }^{\mathrm{R}}-6$ cells. Regulation of the IGF-IR was determined after 6 days of treatment with estradiol (E2, $1 \mathrm{nM})$, tamoxifen (TAM, $1 \mu \mathrm{M})$ and $\mathrm{ICl} 182,780(\mathrm{ICl}, 100 \mathrm{nM})$. Resistant cell lines were grown for 14 days without antiestrogens before harvest. Proteins $(30 \mu \mathrm{g})$ from RIPA extracts $(A, B$ and $D)$ or from Pagano extracts $(C)$ were separated by SDS-PAGE, electroblotted and probed with antibodies to IGF-IR and IRS-1. The lower band in panel $\mathrm{C}$ is the $165 \mathrm{kDa}$ IRS-1 protein whereas the upper band may be a phosphorylated or an unspecific form, which is present in samples from Pagano lysates containing phosphatase and protease inhibitors. Keratin 7 was used as a control for loading.

IGF-IR expression, and this can explain the lack of a growth response to treatment with neutralizing antibodies to IGF-IR.

\section{IRS-1 expression and regulation}

In MCF-7 cells, the IRS-1 protein is the predominant signaling molecule activated via the binding of IGFs to IGF-IR. Moreover, it is the only one of the four IRS molecules significantly upregulated by estradiol (Lee et al. 1999, Molloy et al. 2000). Overexpression of IRS-1 reduces the sensitivity to treatment with ICI 182,780 and it has been suggested that overexpression of IRS-1 in breast tumors might contribute to the development of antiestrogen resistance (Salerno et al. 1999). Therefore, we investigated the IRS-1 expression in MCF-7 cells and in the ICI 182,780- and tamoxifenresistant cell lines. Furthermore, the estrogen and antiestrogen regulation of IRS-1 was measured in MCF-7 and MCF-7/182 ${ }^{\mathrm{R}}-6$ cells.

Figure 3C demonstrates that the expression level of IRS-1 is not increased in the three ICI 182,780resistant cell lines, and nor is it increased in the three tamoxifen-resistant cell lines. On the contrary, the IRS-1 level appears to be slightly reduced in four of the six resistant cell lines. The lower band in Fig. $3 \mathrm{C}$ is the $165 \mathrm{kDa}$ IRS-1 protein, whereas the upper band is an unidentified protein that is detected by the antibody in samples containing phosphatase inhibitors (Fig. 3C) and not detected in samples without phosphatase inhibitors (Fig. 3D). Both MCF-7 cells and the MCF-7/182 ${ }^{\mathrm{R}}-6$ cells display upregulation of IRS-1 upon treatment with estradiol $(1 \mathrm{nM})$, tamoxifen $(1 \mu \mathrm{M})$ has no effect and ICI $182,780(100 \mathrm{nM})$ decreases the level of IRS-1 (Fig. 3D). Thus, regulation of IRS-1 is similar in MCF-7 and MCF-7/182 ${ }^{\mathrm{R}}-6$ cells, and acquired antiestrogen resistance in these cell lines is not conferred by overexpression of IRS- 1 .

\section{Akt expression and activity}

MCF-7 cells transfected with a constitutive active Akt1 exhibit partial estrogen- and IGF-I-independent growth, are more responsive to the combined treatment with IGF-I and estradiol, and are protected against tamoxifen-induced apoptosis (Ahmad et al. 1999, Campbell et al. 2001). Consequently, Akt expression and activity in MCF-7 cells and six different antiestrogen-resistant cell lines were determined. The expression of total Akt protein was similar in MCF-7 and antiestrogen-resistant cell lines (data not shown). Phosphorylation of threonine 308 and subsequently serine 473 in Akt results in full kinase activity (Vivanco $\&$ Sawyers 2002). Figure 4A shows that treatment of MCF-7 cells with the antiestrogens ICI 182,780, tamoxifen or RU 58,668 had no significant effect on the level of serine 473 phosphorylation of Akt. However, a significantly higher level of pAkt was observed in four of six antiestrogen-resistant cell lines grown with their respective antiestrogen (Fig. 4A, $P<0.05)$. Removal of the respective antiestrogens from the growth medium did not change the level of pAkt in the resistant cell lines MCF-7/182 ${ }^{\mathrm{R}}-6$ and MCF-7/TAM ${ }^{\mathrm{R}}-1$, demonstrating that the pAkt level is independent of the presence of antiestrogen (data not shown). The increase in pAkt was of the order of 1.5to 2-fold. To determine whether the observed increase 
A

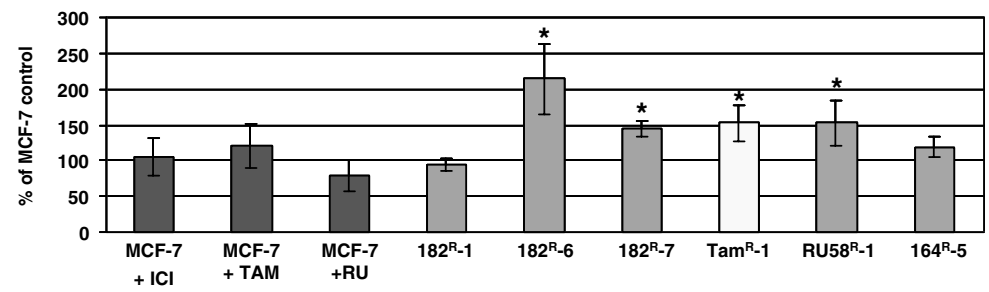

B

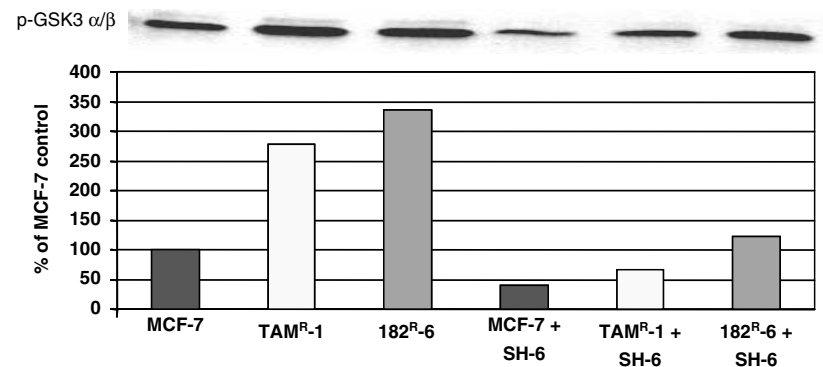

C

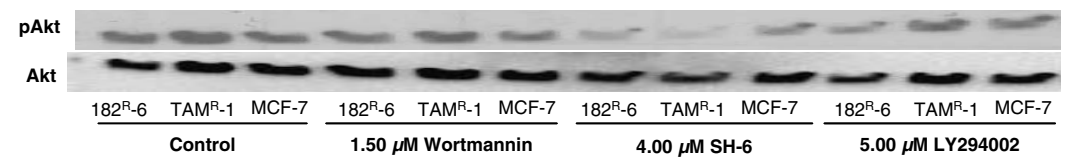

D

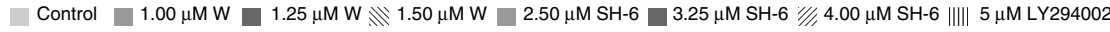

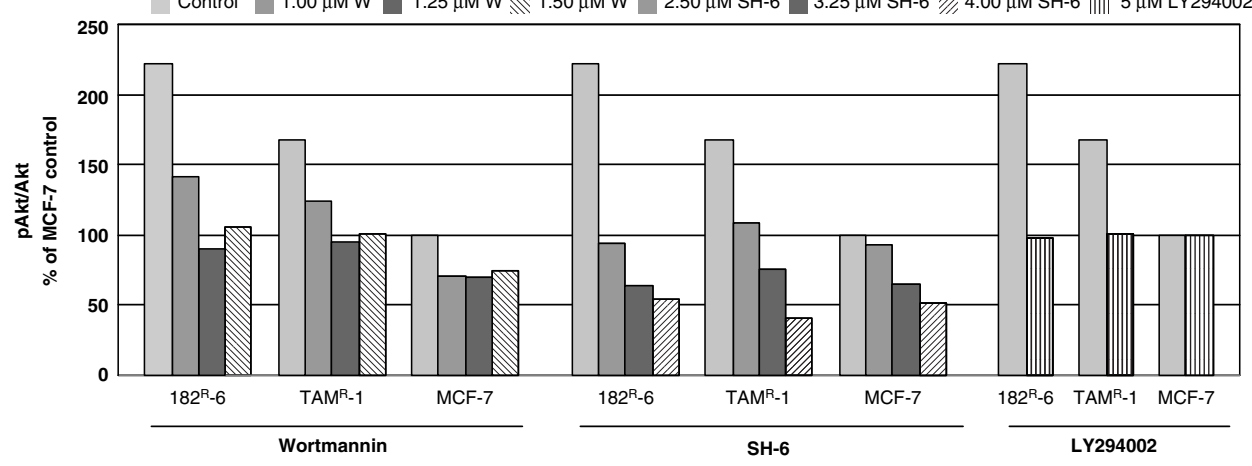

Figure 4 Akt expression and activity. (A) Levels of phosphorylated Akt (pAkt) relative to total Akt in MCF-7 cells treated with ICI $182,780(\mathrm{ICl}, 100 \mathrm{nM})$, tamoxifen (TAM, $1 \mu \mathrm{M})$ or RU 58,668 (RU, $1 \mathrm{nM})$ for 6 days, and in a panel of antiestrogen-resistant cell lines

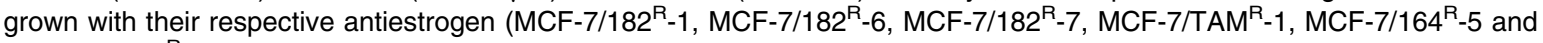
MCF-7/RU58 $\left.{ }^{R}-1\right)$ and harvested with Pagano buffer at $80 \%$ confluence. Proteins $(20 \mu \mathrm{g})$ from total cell extracts from each cell line were separated by SDS-PAGE, electroblotted, probed with antibodies to total Akt and pAkt (Ser473), determined quantitatively and expressed relative to MCF-7 control. Results from four or five independent experiments. Error bars represent S.D. ${ }^{\star}$ Statistically significant difference from MCF-7 control culture, $P<0.05$. (B) Akt kinase activity measured with immunoprecipitated Akt and GSK-3 $\alpha / \beta$ as substrate; $100 \mu \mathrm{g}$ total protein were immunoprecipitated from each cell line grown in their respective maintenance medium or with addition of the Akt inhibitor SH-6 $(3 \mu \mathrm{M})$ for the last 3 days before harvest. The bands of phosphorylated GSK-3 $\alpha / \beta$ protein and the quantitative data are shown. A representative experiment is shown. (C) Immunoblots of pAkt and total Akt in MCF-7, MCF-7/182 ${ }^{\mathrm{R}}-6$ and MCF-7/TAM ${ }^{\mathrm{R}}-1$ cells, grown in maintenance medium, or after treatment with $1.50 \mu \mathrm{M}$ wortmannin, $4.00 \mu \mathrm{M}$ SH-6 or $5.00 \mu \mathrm{M}$ LY294002 for 3 days. This experiment was repeated at least three times with similar results. A single representative Western blot is shown. (D) Quantitative levels of pAkt relative to total Akt and relative to MCF-7 control cells. MCF-7, MCF-7/182 ${ }^{\mathrm{R}}-6$ and MCF-7/TAM ${ }^{\mathrm{R}}-1$ cells, grown in maintenance medium, were treated with the inhibitors wortmannin, SH-6 and LY294002 or with vehicle (DMSO) in control cultures. Increasing concentrations of the inhibitors wortmannin (1.00, 1.25 and $1.50 \mu \mathrm{M})$ and SH-6 $(2.50,3.25$ and $4.00 \mu \mathrm{M})$ were used. The LY294002 concentration was $5.00 \mu \mathrm{M}$. The average from three independent experiments is shown for control cultures and LY294002-treated cultures, whereas a single experiment is shown for each concentration of wortmannin and $\mathrm{SH}-6$. 
in pAkt protein expression reflects increase in Akt kinase activity, a kinase activity assay was performed using the pAkt target GSK-3 $\alpha / \beta$ as substrate for immunoprecipitated Akt protein from lysates of MCF-7 cells and two antiestrogen-resistant cell lines. Figure 4B shows that a marked increase in phosphorylated GSK fusion protein was obtained with lysates from MCF-7/TAM ${ }^{\mathrm{R}}-1$ and MCF-7/182 ${ }^{\mathrm{R}}-6$ cells; $2.8-$ and 3.4-fold respectively, compared with MCF-7 cells. Lysates from cells treated with the Akt inhibitor SH-6 (Kozikowski et al. 2003, Castillo et al. 2004) for $72 \mathrm{~h}$ before harvest contained considerably lower amounts of pAkt activity (Fig. 4B). Two additional independent experiments confirmed the increased Akt kinase activity in MCF-7/182 ${ }^{\mathrm{R}}$-6 cells (3- and 6-fold in these experiments), and lysates from MCF-7/TAM ${ }^{\mathrm{R}}-1$ cells displayed about 2-fold increase. We conclude that the majority of the cell lines with acquired resistance towards antiestrogen treatment display increased levels of pAkt when grown in the presence of the respective antiestrogen. The increased pAkt expression in MCF$7 / 182^{\mathrm{R}}-6$ and $\mathrm{MCF}-7 / \mathrm{TAM}^{\mathrm{R}}-1$ cells is associated with an increase in Akt kinase activity.

\section{Effect of treatment with PI3-K and Akt inhibitors on Akt phosphorylation}

Treatment with protein kinase inhibitors described to be rather specific for PI3-K activity, wortmannin and LY294002 (Davies et al. 2000), and a new Akt inhibitor SH-6 (Kozikowski et al. 2003, Castillo et al. 2004) was performed to elucidate the effect on pAkt expression in MCF-7 cells and two antiestrogenresistant cell lines, MCF-7/TAM ${ }^{\mathrm{R}}-1$ and MCF-7/ $182^{\mathrm{R}}-6$. Figure $4 \mathrm{C}$ shows a representative Western blot with pAkt and total Akt expression in untreated cells and after 3 days of treatment with the indicated inhibitors. MCF-7 cells were grown in control medium and the antiestrogen-resistant cell lines were grown with their respective antiestrogen, tamoxifen or ICI 182,780 . Treatment with $1.50 \mu \mathrm{M}$ wortmannin or $4.00 \mu \mathrm{M} \mathrm{SH}-6$ causes a decrease in the levels of pAkt in all three cell lines, compared with the respective control cells, whereas $5.00 \mu \mathrm{M}$ LY294002 preferentially reduces the pAkt levels in the two antiestrogenresistant cell lines. The quantification in Fig. 4D verifies the increased pAkt expression in MCF-7/ $182^{\mathrm{R}}-6$ and $\mathrm{MCF}-7 / \mathrm{TAM}^{\mathrm{R}}-1$ cells compared with MCF-7 cells (data from three independent experiments). Treatment with wortmannin $(1.00,1.25$ or $1.50 \mu \mathrm{M}$ ) for 3 days reduces the pAkt level in the two antiestrogen-resistant cells down to about MCF-7 level. Wortmannin has a small inhibitory effect on
pAkt expression in MCF-7 cells. SH-6 (2.50, 3.50 and $4.00 \mu \mathrm{M})$ exerts a dose-dependent effect on pAkt expression in MCF-7, MCF-7/TAM ${ }^{\mathrm{R}}-1$ and MCF-7/ $182^{\mathrm{R}}-6$ cells, and the reduction in pAkt expression is more pronounced than with wortmannin treatment. LY294002 $(5.00 \mu \mathrm{M})$ exerts a reproducible reduction in pAkt level in the two antiestrogen-resistant cell lines down to MCF-7 level, and no effect on the low pAkt expression in MCF-7 cells was observed (data from three independent experiments). We conclude that all three protein kinase inhibitors are able to reduce the pAkt level in the antiestrogen-resistant cell lines, and wortmannin and SH-6 also reduce the pAkt level in MCF-7 cells.

\section{Effect of protein kinase inhibitors LY294002, wortmannin and SH-6 on growth of MCF-7, MCF-7/TAM ${ }^{\mathrm{R}}-1$, MCF-7/182 ${ }^{\mathrm{R}}-6$ and MCF-7/ RU58 ${ }^{\mathrm{R}}-1$ cells}

Dose-response growth experiments with 6 days treatment with the inhibitors are shown in Fig. 5A, B and C. MCF-7 cells were grown in control medium with $1 \%$ FCS whereas the antiestrogen-resistant cells (MCF-7/TAM ${ }^{\mathrm{R}}-1, \quad \mathrm{MCF}-7 / 182^{\mathrm{R}}-6$ and MCF-7/ RU58 $\left.{ }^{\mathrm{R}}-1\right)$ were grown in the presence of their respective antiestrogen, tamoxifen, ICI 182,780 or RU 58,668. LY294002 exerts a dose-dependent inhibition of growth of MCF-7, MCF-7/TAM ${ }^{\mathrm{R}}-1$ and MCF-7/ $182^{\mathrm{R}}-6$ cells and no significant difference in the response of MCF-7 cells and antiestrogen-resistant cells is observed (Fig. 5A). Wortmannin treatment did not significantly affect growth of MCF-7 or MCF-7/ $\mathrm{TAM}^{\mathrm{R}}-1$ cells up to $1.25 \mu \mathrm{M}$ concentration, whereas a statistically significant reduction in growth of the MCF-7/182R -6 cells was observed from 0.50 to $1.25 \mu \mathrm{M}$ wortmannin $(P<0.05$; Fig. 5B). Treatment with increasing concentrations of SH-6 resulted in a dose-dependent growth inhibition from $2 \mu \mathrm{M}$ of both resistant cell lines and also MCF-7 cells (Fig. 5C). However, the antiestrogen-resistant cell lines were significantly more sensitive to treatment with $\mathrm{SH}-6$ than the parental MCF-7 cells: MCF-7/182 ${ }^{\mathrm{R}}-6$ cells from $2 \mu \mathrm{M}$ and higher concentrations, $\mathrm{MCF}-7 / \mathrm{TAM}^{\mathrm{R}}$ 1 at 3 and $4 \mu \mathrm{M}(P<0.05)$.

After the initial dose-response experiments, a number of growth experiments were conducted with fixed concentrations of inhibitors. The concentrations were chosen in the range in which a differential effect was observed between the MCF-7 cell line and the antiestrogen-resistant cell lines. Furthermore, the MCF-7/ RU58 ${ }^{\mathrm{R}}-1$ cell line was included. Cells treated with equal concentrations of inhibitor were tested for a 


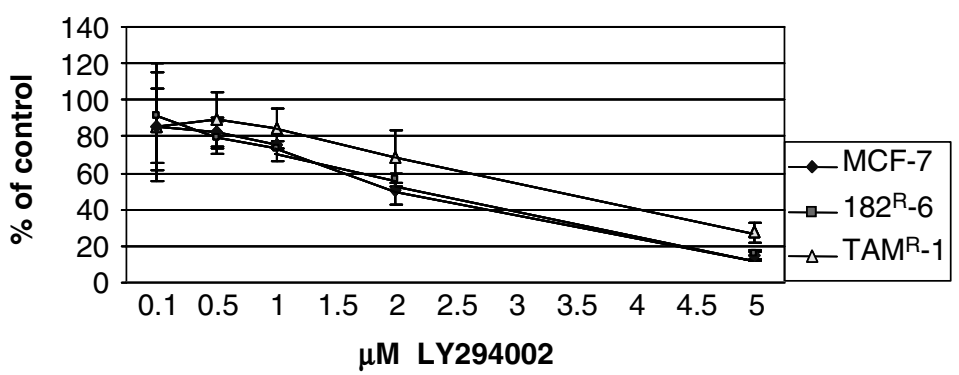

$\mathbf{B}$

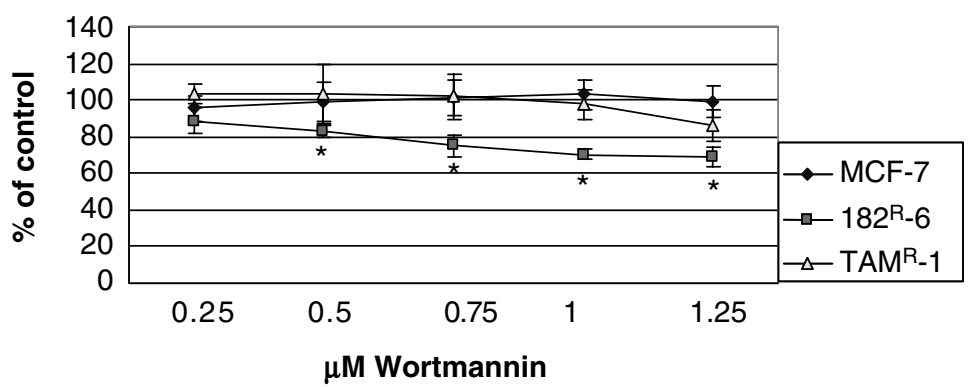

C

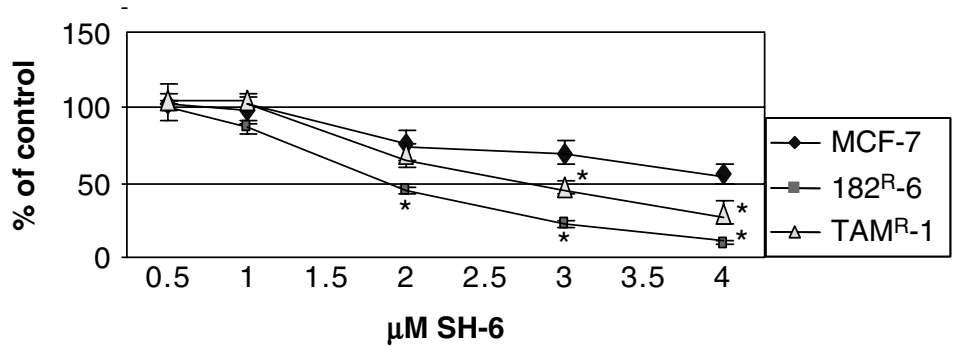

D

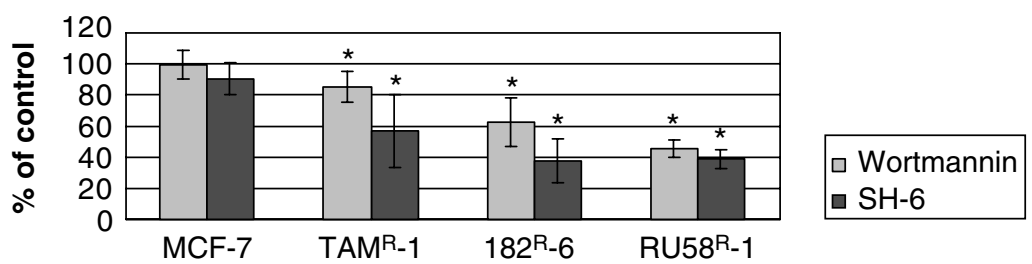

Figure 5 Growth responses of MCF-7 and antiestrogen-resistant cell lines to the inhibitors LY294002, wortmannin or SH-6. Doseresponse growth experiments are shown for the MCF-7, the MCF-7/182 ${ }^{\mathrm{R}}-6$ and the MCF-7/TAM ${ }^{\mathrm{R}}-1$ cell lines. These cell lines were treated for 6 days with increasing concentrations of the PI3-K inhibitors (Wortmannin and SH-6) LY294002 (A), wortmannin (B) or the Akt inhibitor SH-6 (C). At least three independent experiments were performed and a representative result is shown. The growth effects were tested with fixed concentrations of inhibitors (Wortmannin and SH-6) and the MCF-7/RU58 ${ }^{\mathrm{R}}-1$ cell line was also included (D). Wortmannin and $\mathrm{SH}-6$ were used at 1.25 and $2.5 \mu \mathrm{M}$ respectively, for the MCF-7, the MCF-7/182 ${ }^{\mathrm{R}}-6$ and the MCF-7/TAM ${ }^{\mathrm{R}}-1$ cell lines. For the MCF-7/RU58 ${ }^{\mathrm{R}}-1$ cell line wortmannin and SH-6 were used at 1.00 and $3.00 \mu \mathrm{M}$ respectively. These data are mean values pooled from six independent experiments (wortmannin treatment of MCF-7 and MCF-7/TAM ${ }^{\mathrm{R}}-1$ ), five independent experiments (wortmannin treatment of MCF-7/182 ${ }^{\mathrm{R}}-6$, SH-6 treatment of MCF-7, MCF-7/182 ${ }^{\mathrm{R}}-6$ and MCF-7/TAM ${ }^{\mathrm{R}}-1$ ) or three independent experiments (wortmannin and SH-6 treatment of MCF-7/RU58 ${ }^{\mathrm{R}}-1$ ). MCF-7 cells were grown in control medium and the antiestrogen-resistant cell lines, MCF-7/182 ${ }^{R}-6, M C F-7 / T^{2} M^{R}-1$ and MCF-7/RU58 ${ }^{R}-1$ were grown in their respective maintenance medium. Cell numbers were determined by a colorimetric assay and expressed relative to the respective culture grown without PI3-K or Akt inhibitor. Error bars represent S.D. *Significant difference between MCF-7 cells and antiestrogenresistant cells treated with equal concentrations of inhibitor, $P<0.05$. 
preferential growth inhibition of resistant cells by comparing the effect on MCF-7 cells and resistant cells. When tested at $1.25 \mu \mathrm{M}$ and $2.50 \mu \mathrm{M}$, respectively, wortmannin $(n=6)$ and SH-6 $(n=5)$ had no significant effect on the growth of MCF-7 cells (Fig. 5D). However, a small but significant preferential inhibition of the MCF-7/TAM ${ }^{\mathrm{R}}-1$ cell line was observed with $1.25 \mu \mathrm{M}$ wortmannin (mean $85 \%$ of untreated MCF-7/TAM ${ }^{\mathrm{R}}-1$ cells, $n=6$ ). Also the MCF-7/182 ${ }^{\mathrm{R}}-6$ and the MCF-7/RU58 ${ }^{\mathrm{R}}-1$ cell lines were preferentially growth inhibited by wortmannin (mean $63 \%, n=5$ and mean $45 \%, n=3$ respectively). Both the MCF-7/TAM ${ }^{\mathrm{R}}-1$ (mean $57 \%, n=5$ ) and the $\mathrm{MCF}-7 / 182^{\mathrm{R}}-6$ (mean $38 \%, n=5$ ) cell lines were preferentially growth inhibited by $2.50 \mu \mathrm{M} \mathrm{SH}-6$ and the MCF-7/RU58 ${ }^{\mathrm{R}}-1$ cell line (mean $39 \%, n=3$ ) was preferentially growth inhibited by $3.00 \mu \mathrm{M}$ SH-6 (Fig. 5D). These growth studies indicate that MCF-7/ $182^{\mathrm{R}}-6, \mathrm{MCF}-7 / \mathrm{TAM}^{\mathrm{R}}-1$ and the MCF-7/RU58 ${ }^{\mathrm{R}}-1$ cells are dependent on signaling via the PI3-K/Akt pathway to enable them to grow in the presence of the antiestrogen.

\section{PTEN expression and activity}

PTEN is a tumor suppressor gene encoding a phosphatase, which dephosphorylates PIP-3, the product of the PI3-K (Li et al. 1998, Fry 2001). Loss of PTEN protein expression or function leads to increased activation of Akt and could be a causal factor for the increased pAkt expression and activity in antiestrogen-resistant cell lines. Western blot analyses and quantification of PTEN expression in MCF-7 and antiestrogen-resistant cell lines did not reveal reduced PTEN levels in the resistant cell lines (Fig. 6A). On the contrary, compared with MCF-7 control cultures, four out of five antiestrogen-resistant cell lines had significantly increased levels of PTEN. However, when the PTEN levels in the tamoxifen-resistant cell line and the ICI-resistant cell lines were compared with the levels in MCF-7 cells treated for $48 \mathrm{~h}$ with tamoxifen or ICI 182,780 , respectively, no significant changes were found. This may be explained by the antiestrogeninduced increase in PTEN expression in MCF-7 cells of $25-50 \%$ (Fig. 6A). The most pronounced and also statistically significant increase in PTEN expression in MCF-7 cells was observed with the most potent antiestrogen ICI 182,780. Mutations often occur in the PTEN gene, leading to inactive protein ( $\mathrm{Li}$ et al. 1998). Therefore, phosphatase activity of immunoprecipitated PTEN protein was determined. The PTEN levels and the phosphatase activity with PIP-3 as substrate are shown in Fig. 6B and $\mathrm{C}$ respectively. The specific phosphatase activity is similar in MCF-7, MCF-7/TAM ${ }^{\mathrm{R}}-1, \mathrm{MCF}-7 /$ $182^{\mathrm{R}}-6$ and MCF-7/RU58 ${ }^{\mathrm{R}}-1$ cells (Fig. 6C). In accordance with published data indicating that the prostate cancer cell line PC-3 has lost PTEN expression (Vlietstra et al. 1998), no PTEN protein or phosphatase activity was detected in these cells. The unaltered PTEN expression and activity in the antiestrogen-resistant cell lines exclude PTEN as a causal factor for the increased pAkt expression in the antiestrogen-resistant cell lines.

\section{Discussion}

Development of resistance to treatment may occur from several alterations in the cancer cells. These changes may be directed towards protection from the drug through inactivation of the active compound, decreased uptake or increased export. Increased growth and survival promoting changes may also render the cells less responsive to treatment. Thus, resistance may arise from further genetic changes in genes involved in tumorigenesis, such as oncogenes, tumor suppressor genes and stability genes (Vogelstein \& Kinzler 2004).

In this study, we have used a model system developed to mimic the mechanisms that may result in antiestrogen resistance in breast cancer patients initially responsive to therapy and progressing during treatment. We have investigated the expression and function of several of the components in the IGF-I signaling cascade illustrated in Fig. 1. Neutralization of IGF action may be achieved through many strategies (Jerome et al. 2004) and we have used the neutralizing antibodies $\alpha$-IR3 first described by Arteaga and Osborne in 1989. Our MCF-7 cells respond to treatment with $\alpha$-IR3 with a decrease in growth of $20 \%$, demonstrating that the MCF-7 cells signal through the IGF-IR pathway to maintain rapid cell growth in control medium. However, neither growth of a tamoxifen- nor an ICI 182,780-resistant cell line was affected by treatment with $\alpha$-IR3. The lack of response in the resistant cells can be explained by the observed lack or severely reduced level of IGF-IR in the cells. IGF-IR is described to be an estrogen-inducible protein (Stewart et al. 1990), and in accordance we observed estrogen induction and antiestrogen reduction of IGF-IR protein in our MCF-7 cells. In a previous paper from our laboratory, we have published data showing that resistance to the pure steroidal antiestrogen ICI 182,780 was not associated with a general loss of ERs or lack of estrogen responsiveness (Larsen et al. 1997). However, we found a reduced level of ER $\alpha$ expression and a 
A PTEN protein levels

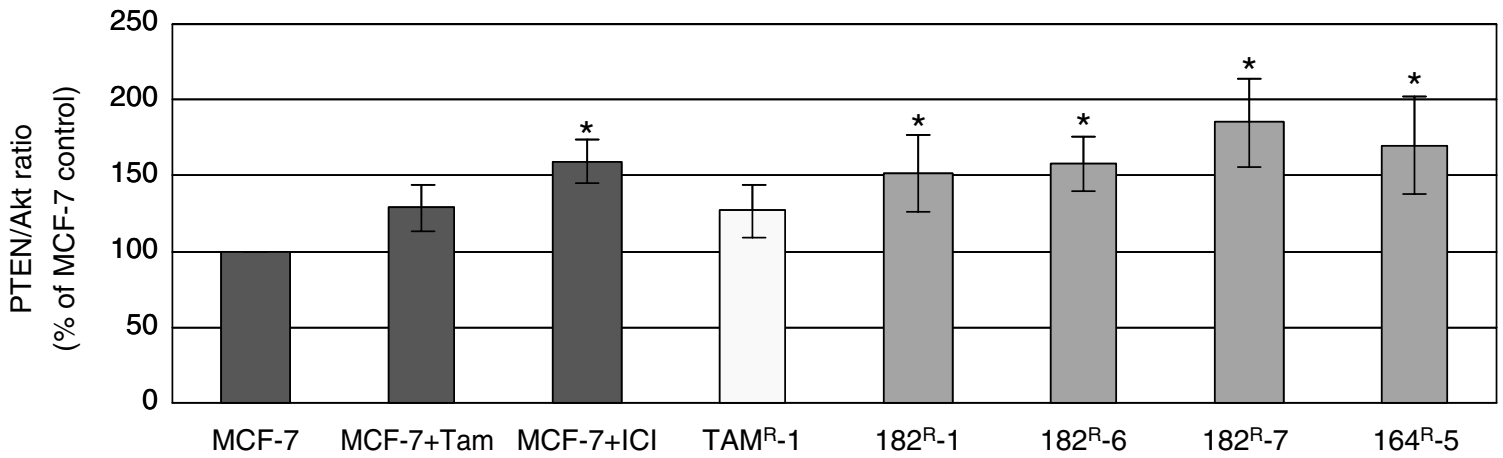

B Immunoprecipitation

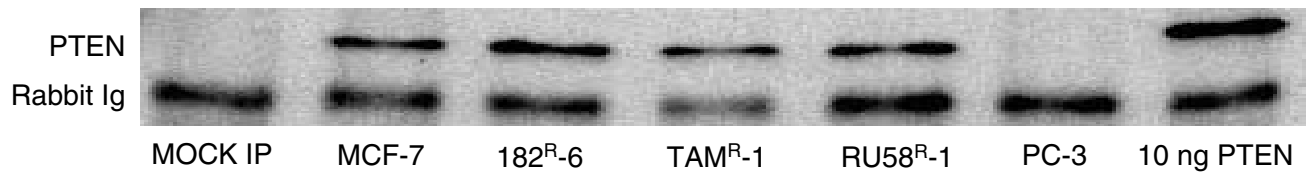

C Lipid phosphatase assay

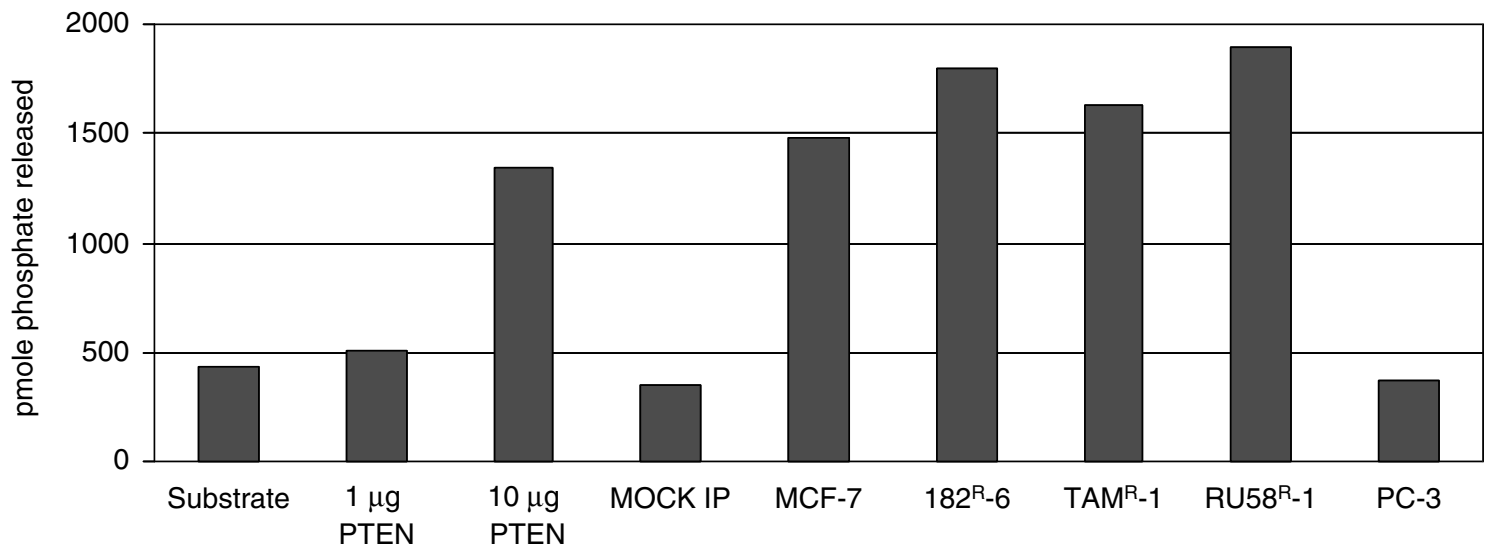

Figure 6 PTEN expression and activity. (A) PTEN protein levels in MCF-7 cells treated with $1 \mu \mathrm{M}$ tamoxifen or $100 \mathrm{nM}$ ICI 182,780 for $48 \mathrm{~h}$ and in five different antiestrogen-resistant cell lines grown in maintenance medium. Mean values from at least four independent experiments are shown. Error bars represent S.D. ${ }^{*}$ Significant difference from MCF-7 control cell cultures $(P<0.05)$. (B) Immunoprecipitated PTEN from $2 \mathrm{mg}$ total protein (Pagano lysate without phosphatase inhibitors) from MCF-7 cells grown in control medium with vehicle $(0.1 \%$ DMSO) and antiestrogen-resistant cells grown in maintenance medium for $4-5$ days. Human PC-3 prostate cancer cells and His-tagged human recombinant PTEN were used as negative and positive controls respectively. (C) Result from PTEN lipid phosphatase assay with the same cell lysates as shown in panel B. The experiment was performed twice with identical results.

complete loss of progesterone receptor expression in both ICI 182,780- and also tamoxifen-resistant cells (Lykkesfeldt et al. 1994, Larsen et al. 1997, Madsen et al. 1997). A reduced level of the estrogen-inducible cathepsin D mRNA and the antiapoptotic protein Bcl-2 has also been found in our antiestrogen-resistant cell lines (Larsen et al. 1997, 2001, Christensen et al.
2004). The mechanisms involved in the loss of IGF-IR and progesterone receptor expression in the antiestrogen-resistant cell lines is unknown at present, but it has been suggested that low progesterone receptor expression may be a result of increased growth factor signaling or constitutively active PI3-K or Akt (Cui et al. 2003). The observation that the level of the 
signaling molecule IRS-1 was either slightly reduced or unchanged in the resistant cells concomitant with maintenance of a normal hormonal regulation of the protein expression is in concert with the observations for other estrogen-regulated proteins in these antiestrogen-resistant cell lines (Larsen et al. 1997).

The Akt pathway is activated by growth factors, growth factor receptors, cytokines and integrins and signaling through PI3-K/Akt is important for regulation of growth and survival of both normal cells and cancer cells (Fry 2001, Franke et al. 2003, Wendel et al. 2004). The PI3-K is a superfamily of at least 12 members (Fry 2001), and Akt consists of three members $(\mathrm{PKB} \alpha / \mathrm{Akt} 1, \mathrm{PKB} \beta / \mathrm{Akt} 2$ and $\mathrm{PKB} \gamma / \mathrm{Akt} 3)$ expressed by three different genes (Nicholson \& Anderson 2002). In our analysis of Akt expression we observed no difference in total Akt level in MCF-7 and antiestrogen-resistant cells. However, four of the six analysed antiestrogen-resistant cell lines displayed a statistically significant increase in the pAkt level. MCF-7 cells have been shown to contain low levels of the Akt-3 isoform (Faridi et al. 2003) and this was confirmed in another recent publication in which MCF-7 cells were found to express both Akt1 and Akt2, although the level of total Akt2 was low and phosphorylated Akt2 was undetectable in MCF-7 cells and tamoxifen-resistant cells (Jordan et al. 2004). These data indicate that it may be the phosphorylated form of the Aktl isoform which is upregulated in our antiestrogen-resistant cell lines, but the antibody used in our study detects all three Akt isoforms; studies are in progress to elucidate which isoform is phosphorylated in our cell lines. The level of pAkt overexpression in the resistant cell lines was 2-fold or lower. Therefore, the Akt kinase activity was determined in two of the antiestrogen-resistant cell lines, MCF-7/182 ${ }^{\mathrm{R}}-6$ and MCF-7/TAM ${ }^{\mathrm{R}}-1$, and we could confirm that pAkt overexpression was associated with increased Akt kinase activity.

In order to explore whether the increase in pAkt could be causally involved in the ability of the cells to grow in the presence of antiestrogen, three different inhibitors of Akt phosphorylation was used. The PI3-K inhibitors wortmannin and LY294002 exerted a substantial reduction in pAkt expression in the resistant cell lines MCF-7/182 ${ }^{\mathrm{R}}-6$ and MCF-7/TAM ${ }^{\mathrm{R}}$ 1, and the new Akt inhibitor SH-6 was very efficient with respect to inhibition of pAkt expression and also with respect to reduction of pAkt kinase activity. The growth studies revealed a somewhat surprising result in that LY294002 inhibited growth similarly in all cell lines, irrespective of the pAkt levels. Identical inhibition of growth of MCF-7 cells and a tamoxifen-resistant cell line, TAM-R, expressing increased pAkt was also observed by Jordan et al. (2004). The LY294002 is a potent inhibitor of PI3-K activity but it also inhibits casein kinase 2 (Davies et al. 2000). Furthermore, a study has shown that LY294002 was able to compete with estradiol for binding to ERs in a cell line transfected with both ER $\alpha$ and ER $\beta$ (Limón et al. 2003). Thus, LY294002 blocks Akt phosphorylation but it may also interfere with other processes in the cells including the ER $\alpha$ signaling pathways. We suggest that the effect of LY294002 on growth of MCF-7 cells may be explained by inhibition of ER $\alpha$ signaling whereas the antiestrogen-resistant cells are growth inhibited through blockage of the Akt signaling. In contrast to LY294002, both the PI3-K inhibitor wortmannin and the Akt inhibitor SH-6 exerted a preferential inhibition of the antiestrogenresistant cell lines compared with parental MCF-7 cells, suggesting that the antiestrogen-resistant cell lines require signaling through Akt to survive and grow in the presence of antiestrogens. The SH- 6 compound is a rationally designed PIP- 3 analogue and a recent publication has shown that this compound (called PIA6 in the paper) increased apoptosis in cancer cell lines with high levels of endogenous Akt activity and had a significantly smaller effect in cell lines with low Akt activity (Castillo et al. 2004). Studies are planned to investigate whether the increased Akt activity in the antiestrogen-resistant cell lines protects the cells from apoptotic signals and alters cell cycle regulation. The serine/threonine kinase Akt is a multifunctional protein mediating both cell proliferation and survival through many pathways including cross-talk with the ER $\alpha$ (Vivanco \& Sawyers 2002, Johnston et al. 2003, Brazil et al. 2004, Lawlor \& Alessi 2001) and it may be a major target for therapy of selected cancer patients with overexpression of pAkt (Hanada et al. 2004). Furthermore, pAkt expression may be used as a predictive marker for treatment failure to endocrine therapy (Pérez-Tenorio et al. 2002, Stål et al. 2003).

An important negative regulator of PI3-K/Akt signaling is the phosphatase encoded by the tumor suppressor gene PTEN (Li et al. 1998, Fry 2001), and absent or reduced PTEN has been found in approximately one-third of women with lymph node negative breast cancers (Shi et al. 2003). We did not observe decreased PTEN levels or activity in our antiestrogenresistant cell lines. On the contrary, the potent antiestrogen ICI 182,780 increased the level of PTEN in MCF-7 cells by approximately $50 \%$ and the ICI 182,780-resistant cell lines displayed an increase in PTEN level comparable with MCF-7 cells treated with ICI 182,780. The less potent antiestrogen tamoxifen 
only induced a small increase in PTEN expression in MCF-7 cells and similarly the tamoxifen-resistant cell line had a PTEN level comparable with MCF-7 cells treated with tamoxifen. Thus, our PTEN analyses do not support a causal involvement of this protein in the increased pAkt level in antiestrogen-resistant cells.

Several upstream factors of Akt will be of interest for analyses to unravel the genetic changes that may result in increased pAkt levels. Thus, increased levels of the p85 regulatory subunit of the PI3-K has been observed in a series of breast tumors (Gershtein et al. 1999), mutations in the PIK3CA gene encoding the p1 $10 \alpha$ catalytic subunit of PI3-K were found in $40 \%$ of primary breast cancers (Campbell et al. 2004) and members of the PKC family may also be potential upstream signaling factors (Mackay \& Twelves 2003). Recent data have shown that upregulation of PKC- $\delta$ contributes to antiestrogen resistance in human mammary tumor cells, including the MCF-7/TAM ${ }^{\mathrm{R}}$ 1 and MCF-7/182 ${ }^{\mathrm{R}}-6$ cell lines used in this study (Nabha et al. 2005). Inhibition of PKC- $\delta$ by the inhibitor rottlerin blocks Akt signaling (Nabha et al. 2005), and we suggest that the enhanced Akt activation in our antiestrogen-resistant cell lines may arise from increased signaling via PKC- $\delta$. The heat shock protein 90 (Hsp90) is a molecular chaperone important for stabilization of several proteins including Akt (Neckers \& Ivy 2003). A recent publication has shown that treatment of our tamoxifen-resistant cell lines with the Hsp90 inhibitor geldanamycin resulted in both ER $\alpha$ and Akt degradation (Beliakoff et al. 2003), and it would be interesting to determine whether Hsp90 inhibitors may have a selective inhibitory effect on antiestrogen-resistant cell lines.

This study has shown that an increased level of pAkt is a common phenomenon in a panel of cell lines with acquired resistance to different antiestrogens such as tamoxifen, ICI 182,780 and RU 58,668. Cell lines with increased pAkt also displayed increased Akt kinase activity. pAkt expression could be extensively reduced by both PI3-K and Akt inhibitors, and a more pronounced growth inhibition of cell lines with high pAkt expression was observed with both the PI3-K inhibitor wortmannin and the Akt inhibitor SH-6. Therefore, we conclude that PI3-K/Akt signaling is causally involved in antiestrogen resistance in this model system. Although a large clinical study did not disclose pAkt to be a prognostic factor in breast cancer (Panigrahi et al. 2004), the clinical significance of our study is supported by two smaller studies. In one study, pAkt expression predicted a worse outcome from endocrine therapy (Pérez-Tenorio et al. 2002). In another study, no effect of tamoxifen therapy was observed in ER-positive and Akt-positive patients, whereas a significant benefit from tamoxifen therapy was observed in ER-positive and Akt-negative patients (Stål et al. 2003). Therefore, Akt may be a new target for therapy for patients with resistance to endocrine therapy.

\section{Acknowledgements}

We would like to thank Inger Heiberg for skilful technical assistance. ICI 182,780 was kindly provided by AstraZeneca (Macclesfield, UK) and RU 58,668 was a gift from Roussel Uclaf (Paris, France). Keratin 7 antibody was a gift from Professor Jiri Bartek, Danish Cancer Society.

\section{Funding}

The work has been supported by grants from the Danish Cancer Society, the Hansen-Bille Brahe Family Foundation, the Georg Bjørkner and wife Ellen Bjørkner's Foundation and the Danish Research Agency. There is no conflict of interest that would prejudice impartiality.

\section{References}

Ahmad S, Singh N \& Glazer RI 1999 Role of AKT1 in $17 \beta$-estradiol- and insulin-like growth factor I (IGF-I)dependent proliferation and prevention of apoptosis in MCF-7 breast carcinoma cells. Biochemical Pharmacology 58 425-430.

Ali S \& Coombes RC 2002 Endocrine-responsive breast cancer and strategies for combating resistance. Nature Reviews Cancer 2 101-112.

Arteaga CL \& Osborne CK 1989 Growth inhibition of human breast cancer cells in vitro with an antibody against the type I somatomedin receptor. Cancer Research 49 6237-6241.

Baserga R, Hongo A, Rubini M, Prisco M \& Valentinis B 1997 The IGF-I receptor in cell growth, transformation and apoptosis. Biochimica et Biophysica Acta 1332 F105-126.

Beliakoff J, Bagatell R, Paine-Murrieta G, Taylor CW, Lykkesfeldt AE \& Whitesell L 2003 Hormone-refractory breast cancer remains sensitive to the antitumor activity of heat shock protein 90 inhibitors. Clinical Cancer Research 9 4961-4971.

Brazil DP, Yang Z-Z \& Hemmings BA 2004 Advances in protein kinase B signalling: AKTion on multiple fronts. Trends in Biochemical Sciences 29 233-242.

Briand P \& Lykkesfeldt AE 1984 Effect of estrogen and antiestrogen on the human breast cancer cell line MCF-7 adapted to growth at low serum concentration. Cancer Research 44 1114-1119. 
Campbell IG, Russell SE, Choong DYH, Montgomery KG, Ciavarella ML, Hooi CSF, Cristiano BE, Pearson RB \& Phillips WA 2004 Mutation of the PIK3CA gene in ovarian and breast cancer. Cancer Research 64 7678-7681.

Campbell RA, Bhat-Nakshatri P, Patel NM, Constantinidou D, Ali S \& Nakshatri H 2001 Phosphatidylinisitol 3-kinase/AKT-mediated activation of estrogen receptor alpha: a new model for anti-estrogen resistance. Journal of Biological Chemistry 276 9817-9824.

Castillo SS, Brognard J, Petukhov PA, Zhang C, Tsurutani J, Granville CA et al. 2004 Preferential inhibition of Akt and killing of Akt-dependent cancer cells by rationally designed phosphatidylinositol ether lipid analogues. Cancer Research 64 2782-2792.

Chan CMW, Lykkesfeldt AE, Parker MG \& Dowsett M 1999 Expression of nuclear receptor interacting proteins TIF-1, SUG-1, receptor interacting protein 140, and corepressor SMRT in tamoxifen-resistant breast cancer. Clinical Cancer Research 5 3460-3467.

Christensen GL, Jepsen JS, Fog CK, Christensen IJ \& Lykkesfeldt AE 2004 Sequential versus combined treatment of human breast cancer cells with antiestrogens and the vitamin D analogue EB1089 and evaluation of predictive markers for vitamin D treatment. Breast Cancer Research and Treatment 85 53-63.

Clarke R, Liu MC, Bouker KB, Gu Z, Lee RY, Zhu Y, Skaar TC, Gomez B, O’Brian K, Wang Y \& HilakiviClarke LA 2003 Antiestrogen resistance in breast cancer and the role of estrogen receptor signaling. Oncogene 22 7316-7339.

Come SE, Buzdar AU, Arteaga CL, Brodie AM, Davidson NE, Dowsett M et al. 2003 Second international conference on recent advances and future directions in endocrine manipulation of breast cancer: summary consensus statement. Clinical Cancer Research 9 (Suppl) $443 \mathrm{~s}-446 \mathrm{~s}$.

Cui X, Zang P, Deng W, Oesterreich S, Lu Y, Mills GB \& Lee AV 2003 Insulin-like growth factor-I inhibits progesterone receptor expression in breast cancer cells via the phosphatidylinositol 3-kinase/Akt/mammalian target of rapamycin pathway: progesterone receptor as a potential indicator of growth factor activity in breast cancer. Molecular Endocrinology 17 575-588.

Davies SP, Reddy H, Caivano M \& Cohen P 2000 Specificity and mechanism of action of some commonly used protein kinase inhibitors. Biochemical Journal 351 95-105.

de Cremoux P, Tran-Perennou C, Brockdorff BL, Boudou E, Brünner N, Magdelénat H \& Lykkesfeldt AE 2003 Validation of real-time RT-PCR for analysis of human breast cancer cell lines resistant or sensitive to treatment with antiestrogen. Endocrine-Related Cancer 10 409-418.

Encarnacion CA, Ciocca DR, McGuire WL, Clark GM, Fuqua SAW \& Osborne CK 1993 Measurement of steroid hormone receptors in breast cancer patients on tamoxifen. Breast Cancer Research and Treatment 26 237-246.

Faridi J, Wang L, Endemann G \& Roth RA 2003 Expression of constitutively active Akt-3 in MCF-7 breast cancer cells reverses the estrogen and tamoxifen responsivity of these cells in vivo. Clinical Cancer Research 9 2933-2939.

Fog CK, Christensen IJ \& Lykkesfeldt AE Characterization of a human breast cancer cell line, MCF-7/RU58 ${ }^{\mathrm{R}}-1$, resistant to the pure antiestrogen RU58,668. Breast Cancer Research and Treatment 91 133-144.

Franke TF, Hornik CP, Segev L, Shostak GA \& Sugimoto C 2003 PI3K/Akt and apoptosis: size matters. Oncogene 22 8983-8998.

Fry MJ 2001 Phosphoinositide 3-kinase signalling in breast cancer: how big a role might it play? Breast Cancer Research 3 304-312.

Georgescu M-M, Kirsch KH, Akagi T, Shishido T \& Hanafusa H 1999 The tumor-suppressor activity of PTEN is regulated by its carboxyl-terminal region. PNAS 96 10182-10187.

Gershtein ES, Shatskaya VA, Ermilova VD, Kushlinsky NE \& Krasil'nikov MA 1999 Phosphatidylinositol 3-kinase expression in human breast cancer. Clinica Chimica Acta $28759-67$.

Hanada M, Feng J \& Hemmings BA 2004 Structure, regulation and function of $\mathrm{PKB} / \mathrm{Akt}-\mathrm{a}$ major therapeutic target. Biochimica et Biophysica Acta $16973-16$.

Howell A \& Howell SJ 2003 New antiestrogens: modulators of estrogen action. In Breast Cancer Management. Application of Clinical and Translational Evidence to Patient Care, edn 2, pp 223-242. Eds J-M Nabholtz, K Tonkin, DM Reese, MS Aapro \& AU Buzdar. Philadelphia: Lippincott Williams \& Wilkins.

Hutcheson IR, Knowlden JM, Madden T-A, Barrow D, Gee JMW, Wakeling AE \& Nicholson RI 2003 Oestrogen receptor-mediated modulation of the EGFR/MAPK pathway in tamoxifen-resistant MCF-7 cells. Breast Cancer Research and Treatment 81 81-93.

Jerome L, Shiry L \& Leyland-Jones B 2003 Deregulation of the IGF axis in cancer: epidemiological evidence and potential therapeutic interventions. Endocrine-Related Cancer 10 561-578.

Jerome L, Shiry L \& Leyland-Jones B 2004 Anti-insulin-line growth factor strategies in breast cancer. Seminars in Oncology 31 54-63.

Johnston SRD, Saccani-Jotti G, Smith IE, Salter J, Newby J, Coppen M, Ebbs SR \& Dowsett M 1995 Changes in estrogen receptor, progesterone receptor, and $\mathrm{pS} 2$ expression in tamoxifen-resistant human breast cancer. Cancer Research 55 3331-3338.

Johnston SRD, Head J, Pancholi S, Detre S, Martin L-A, Smith IE \& Dowsett M 2003 Integration of signal transduction inhibitors with endocrine therapy: an approach to overcoming hormone resistance in breast cancer. Clinical Cancer Research 9 (Suppl) 524s-532s.

Jordan NJ, Gee JMW, Barrow D, Wakeling AE \& Nicholson RI 2004 Increased constitutive activity of PKB/Akt in tamoxifen resistant breast cancer MCF-7 cells. Breast Cancer Research and Treatment 87 167-180. 
Knowlden JM, Hutcheson IR, Jones HE, Madden T, Gee JMW, Harper ME, Barrow D, Wakeling AE \& Nicholson RI 2003 Elevated levels of epidermal growth factor receptor/c-erbB2 heterodimers mediate an autocrine growth regulatory pathway in tamoxifenresistant MCF-7 cells. Endocrinology 144 1032-1044.

Kozikowski AP, Sun H, Brognard J \& Dennis PA 2003 Novel PI analogues selectively block activation of the pro-survival serine/threonine kinase Akt. Journal of the American Chemical Society 125 1144-1145.

Larsen SS, Madsen MW, Jensen BL \& Lykkesfeldt AE 1997 Resistance of human breast-cancer cells to the pure steroidal anti-estrogen ICI 182,780 is not associated with a general loss of estrogen-receptor expression or lack of estrogen responsiveness.

Larsen SS, Egeblad M, Jäättelä M \& Lykkesfeldt AE 1999 Aquired antiestrogen resistance in MCF-7 human breast cancer sublines is not accomplished by altered expression of receptors in the ErbB-family. Breast Cancer Research and Treatment 58 41-56.

Larsen SS, Heiberg I \& Lykkesfeldt AE 2001 Anti-oestrogen resistant human breast cancer cell lines are more sensitive towards treatment with the vitamin D analogue EB1089 than parent MCF-7 cells. British Journal of Cancer $\mathbf{8 4}$ 686-690.

Lawlor MA \& Alessi DR 2001 PKB/Akt: a key mediator of cell proliferation, survival and insulin responses? Journal of Cell Science 114 2903-2910.

Lee AV, Jackson JG, Gooch JL, Hilsenbeck SG, CoronadoHeinsohn E, Osborne CK \& Yee D 1999 Enhancement of insulin-like growth factor signaling in human breast cancer: estrogen regulation of insulin receptor substrate-1 expression in vitro and in vivo. Molecular Endocrinology 13 787-796.

Li J, Simpson L, Takahashi M, Miliaresis C, Myers MP, Tonks N \& Parsons R 1998 The PTEN/MMAC1 tumor suppressor induces cell death that is rescued by the Akt/ protein kinase B oncogene. Cancer Research $\mathbf{5 8}$ 5667-5672.

Limón AMP, Herrera-Muñoz J, Gutiérrez-Sagal A \& Ulloa-Aguirre A 2003 The phosphatidylinositol 3-kinase inhibitor LY294002 binds the estrogen receptor and inhibits $17 \beta$-estradiol-induced transcriptional activity of an estrogen sensitive reporter gene. Molecular and Cellular Endocrinology 200 199-202.

Lundholt BK, Briand P \& Lykkesfeldt AE 2001 Growth inhibition and growth stimulation by estradiol of estrogen receptor transfected human breast epithelial cell lines involve different pathways. Breast Cancer Research and Treatment 67 199-214.

Lykkesfeldt AE, Larsen JK, Christensen IJ \& Briand P 1984 Effects of the antioestrogen tamoxifen on the cell cycle kinetics of the human breast cancer cell line, MCF-7. British Journal of Cancer 49 717-722.

Lykkesfeldt AE, Madsen MW \& Briand P 1994 Altered expression of estrogen-regulated genes in a tamoxifenresistant and ICI 164,384 and ICI 182,780 sensitive human breast cancer cell line, $\mathrm{MCF}-7 / \mathrm{TAM}^{\mathrm{R}}-1$. Cancer Research 54 1587-1595.

Lykkesfeldt AE, Larsen SS \& Briand P 1995 Human breast cancer cell lines resistant to pure anti-estrogens are sensitive to tamoxifen treatment. International Journal of Cancer 61 529-534.

McClelland RA, Barrow D, Madden T-A, Dutkowski CM, Pamment J, Knowlden JM, Gee JMW \& Nicholson RI 2001 Enhanced epidermal growth factor receptor signaling in MCF7 breast cancer cells after long-term culture in the presence of the pure antiestrogen ICI 182,780 (Faslodex). Endocrinology 142 2776-2788.

Mackay HJ \& Twelves CJ 2003 Protein kinase C: a target for anticancer drugs? Endocrine-Related Cancer 10 389-396.

Madsen MW, Reiter BE, Larsen SS, Briand P \& Lykkesfeldt AE 1997 Estrogen receptor messenger RNA splice variants are not involved in antiestrogen resistance in sublines of MCF-7 human breast cancer cells. Cancer Research 57 585-589.

Molloy CA, May FE \& Westley BR 2000 Insulin receptor substrate-1 expression is regulated by estrogen in the MCF-7 human breast cancer cell line. Journal of Biological Chemistry 275 12565-12571.

Nabha SM, Glaros S, Hong M, Lykkesfeldt AE, Schiff R, Osborne K \& Reddy KB 2005 Upregulation of PKC- $\delta$ contributes to antiestrogen resistance in mammary tumor cells. Oncogene 24 3166-3176.

Neckers L \& Ivy SP 2003 Heat shock protein 90. Current Opinion in Oncology 15 419-424.

Nicholson KM \& Anderson NG 2002 The protein kinase $\mathrm{B} /$ Akt signalling pathway in human malignancy. Cellular Signalling 14 381-395.

Osborne CK 1998 Tamoxifen in the treatment of breast cancer. New England Journal of Medicine 339 1609- 1618.

Pagano M, Pepperkok R, Lukas J, Baldin V, Ansorge W, Bartek J \& Draetta G 1993 Regulation of the cell cycle by the cdk2 protein kinase in cultured human fibroblasts. Journal of Cell Biology 121 101-111.

Panigrahi AR, Pinder SE, Chan SY, Paish EC, Robertson JFR \& Ellis IO 2004 The role of PTEN and its signalling pathways, including AKT, in breast cancer, an assessment of relationships with other prognostic factors and with outcome. Journal of Pathology 204 93-100.

Pérez-Tenorio G, Stål O and members of the Southeast Sweden Breast Cancer Group 2002 Activation of AKT/ PKB in breast cancer predicts a worse outcome among endocrine treated patients. British Journal of Cancer 86 540-545.

Salerno M, Sisci D, Mauro L, Guvakova MA, Ando S \& Surmacz E 1999 Insulin receptor substrate 1 is a target for the pure antiestrogen ICI 182,780 in breast cancer cells. International Journal of Cancer 81 299-304.

Schiff R, Massarweh SA, Shou J, Bharwani L, Mohsin SK \& Osborne CK 2004 Cross-talk between estrogen receptor and growth factor pathways as a molecular target for overcoming endocrine resistance. Clinical Cancer Research 10 (Suppl) 331s-336s. 
Shi W, Zhang X, Pintilie M, Ma N, Miller N, Banarjee D, Tsao, M-S, Mak T, Fyles A \& Liu F-F 2003 Dysregulated PTEN-PKB and negative receptor status in human breast cancer. International Journal of Cancer 104 195-203.

Stål O, Pérez-Tenorio G, Åkerberg L, Olsson B, Nordenskjöld B, Skoog L \& Rutqvist LE 2003 Akt kinases in breast cancer and the result of adjuvant therapy. Breast Cancer Research 5 R37-R44.

Stewart AJ, Johnson MD, May FEB \& Westley BR 1990 Role of insulin-like growth factors and the type I insulinlike growth factor receptor in the estrogen-stimulated proliferation of human breast cancer cells. Journal of Biological Chemistry 265 21172-21178.

Van de Velde P, Nique F, Planchon P, Prévost P, Brémaud J, Hameau MC, Magnien V, Philibert D \& Teutsch G 1996 RU 58668: further in vitro and in vivo pharmacological data related to its antitumoral activity. Journal of Steroid Biochemistry and Molecular Biology $59449-457$.
Vivanco I \& Sawyers CL 2002 The phosphatidylinositol 3-kinase-Akt pathway in human cancer. Nature Reviews Cancer 2 489-501.

Vlietstra RJ, van Alewijk DCJG, Hermans KGL, van Steenbrugge GJ \& Trapman J 1998 Frequent inactivation of PTEN in prostate cancer cell lines and xenografts. Cancer Research 58 2720-2723.

Vogelstein B \& Kinzler KW 2004 Cancer genes and the pathways they control. Nature Medicine 10 789-799.

Wendel H-G, de Stanchina E, Fridman JS, Malina A, Ray S, Kogan S, Cordon-Cardo C, Pelletier J \& Lowe SW 2004 Survival signalling by Akt and eIF4E in oncogenesis and cancer therapy. Nature $\mathbf{4 2 8}$ 332-337.

Wiseman LR, Johnson MD, Wakeling AE, Lykkesfeldt AE, May FEB \& Westley BR 1993 Type I IGF receptor and acquired tamoxifen resistance in oestrogen-responsive human breast cancer cells. European Journal of Cancer 29A 2256-2264. 